\title{
Evaluation of Models for Estimating Changes in Fracture Permeability Due to Thermal-Mechanical Stresses in Host Rock Surrounding a Potential Repository
}

\author{
P.A. Berge \\ H.F. Wang \\ R.J. Shaffer \\ S.C. Blair
}

February 18, 1997

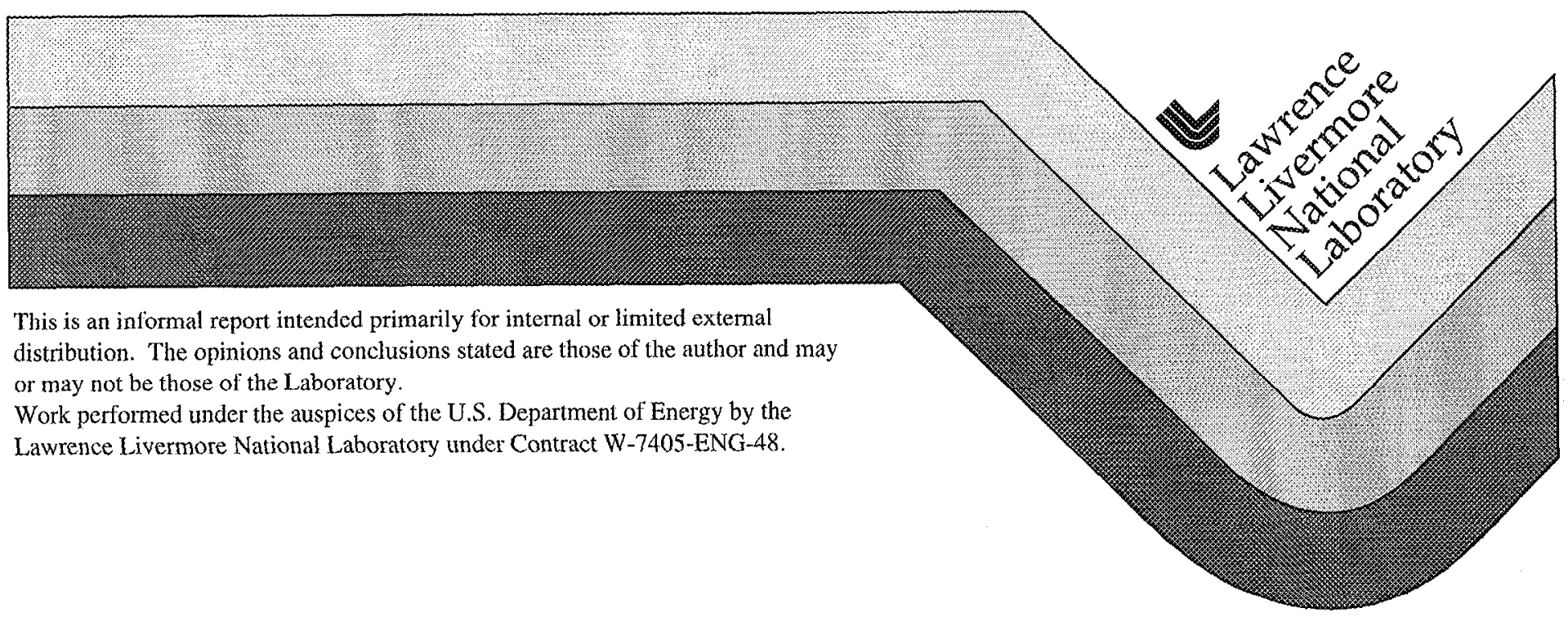




\section{DISCLAIMER}

This document was prepared as an account of work sponsored by an agency of the United States Government. Neither the United States Government nor the University of California nor any of their employees, makes any warranty, express or implied, or assumes any legal liability or responsibility for the accuracy, completeness, or usefulness of any information, apparatus, product, or process disclosed, or represents that its use would not infringe privately owned rights. Reference herein to any specific commercial product, process, or service by trade name, trademark, manufacturer, or otherwise, does not necessarily constitute or imply its endorsement, recommendation, or favoring by the United States Government or the University of California. The views and opinions of authors expressed herein do not necessarily state or reflect those of the United States Government or the University of California, and shall not be used for advertising or product endorsement purposes.

This report has been reproduced directly from the best available copy.

Available to DOE and DOE contractors from the Office of Scientific and Technical Information P.O. Box 62, Oak Ridge, TN 37831

Prices available from (423) 576-8401

Available to the public from the National Technical Information Service

U.S. Department of Commerce

5285 Port Royal Rd.,

Springfield, VA 22161 
EVALUATION OF MODELS FOR ESTIMATING CHANGES IN FRACTURE PERMEABILITY DUE TO THERMO-MECHANICAL STRESSES IN HOST ROCK SURROUNDING A POTENTIAL REPOSITORY

DELIVERABLE NO: SPLF1M4 (LEVEL 4 MILESTONE)

DUE DATE: 18 FEBRUARY 1997

P. A. Berge, H. F. Wang, R. J. Shaffer, S. C. Blair

Lawrence Livermore National Laboratory 
1. INTRODUCTION

2. BACKGROUND

Thermal-

Continu un Colculation …….............3

Continuum Codes: ..........................................................................

Discrete or Distinct Element Codes: ................................................4

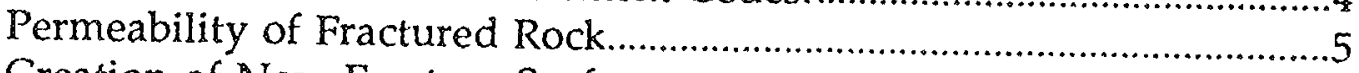

Creation of New Fracture Surface.............................................................5

Simulation of Coupled Thermal-Mechanical-Hydrologic Processes ...6

Comparison of 2-D and 3-D Models......................................................8

3. SUGGESTED PROCEDURE

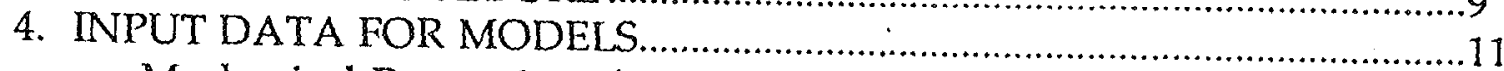

Mechanical Properties of Tuff and Fractures ..............................................11

Thermal Properties of Topopah Spring Tuff............................................13

Fracture Statistics ...................................................................................14

Permeability of Fractures......................................................................14

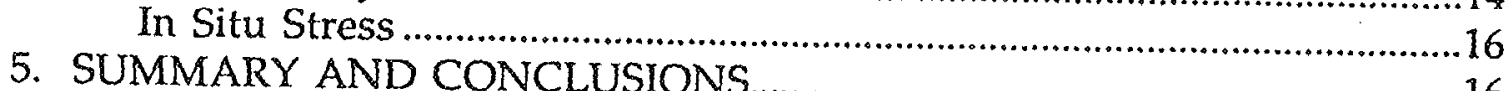

6. REFERENCES 
EVALUATION OF MODELS FOR ESTIMATING CHANGES IN FRACTURE PERMEABILITY DUE TO THERMO-MECHANICAL STRESSES IN HOST ROCK SURROUNDING THE REPOSITORY

DELIVERABLE NO: SPLF1M4 (LEVEL 4 MILESTONE)

DUE DATE: 18 FEBRUARY 1997

by P. A. Berge, H. F. Wang, R. J. Shaffer, S. C. Blair

Lawrence Livermore National Laboratory

\section{INTRODUCTION}

Understanding the hydrologic response of fluids present in the proposed repository horizon to the development of a repository and the subsequent storage of high-level radioactive waste, is crucial to the evaluation of Yucca Mountain as a suitable site for a permanent geologic repository. Moreover, one of the inherent properties of rock that controls moisture movement and fluid flow is the permeability, and the permeability of rock is known to be dependent on stress and temperature. Furthermore, the stress field in the rock surrounding the drifts will be altered by both the excavation of drifts and the heating of the rock associated with waste emplacement and storage. Thus, the hydrologic behavior of rock surrounding emplacement drifts is dependent on the mechanical response of the rock to excavation and waste emplacement. In addition, the proposed repository horizon at Yucca Mountain contains a significant number of fractures, and the mechanical and hydrologic properties of fractured rock are not well understood. Prior work has shown that increasing stress across fractures causes a reduction in fracture aperture, and to the first order, flow in a fracture can be related to the cube of the fracture aperture. Generally, as compressive stress across a fracture is increased, the aperture is reduced, which reduces the fluid flow. More recent work indicates increases in shear stress across a fracture may also reduce the fracture permeability. Finally, while a preliminary understanding of flow in single fractures is now available, it is also widely accepted that the hydrologic behavior of a fractured rock mass is controlled by a few, well connected fractures in the rock mass.

Given this background we provide in this report a methodology to estimate bounds on the changes in fracture permeability due to thermal-mechanical processes associated with excavation of drifts and emplacement of waste. This report is the first milestone associated with Task A of the LLNL initiative to evaluate available methods for estimating changes in fracture permeability surrounding drifts in the Exploratory Studies Facility (ESF) and the potential repository at Yucca Mountain in response to (1) construction-induced stress changes and (2) subsequent thermal pulse effects due to waste emplacement. These results are needed for modeling changes in repository-level moisture movement and seepage (Summary Account TR3C2FB4 and TR3C2FB5). 
This report includes the following sections that have been developed to address the Level 4 Milestone Acceptance Criteria.

Background Literature Review.

This section presents a literature review of discrete element, finite element, and finite difference models and fracture displacement sub-models for the analysis of changes in fracture permeability induced by thermal and mechanical loading. Background literature is critically reviewed, including discussion of the strengths and limitations of different modeling techniques and discussion of twodimensional $(2-d)$ and three-dimensional $(3-d)$ simulations.

Suggested Procedure.

A suggested approach for analysis of changes in fracture permeability is described. This approach is comprised of three steps which include: (1) calculation of stress changes associated with construction and heating, (2) application of strength criteria both for creation of new fractures and for opening or slip of pre-existing fractures, and (3) estimation of the change in permeability of the rock mass using a network flow model. In this approach both theoretical analysis and experimental data are used to estimate statistical distribution functions of parameters that determine transmissivity of the conducting fractures. Moreover, using this approach, different theories and/or numerical codes can be used to implement the separate conceptual steps

Input Data.

A description of the input data required for implementing the methodology is presented. These data include thermal and mechanical properties of Topopah Spring tuff measured in the laboratory and in the field; fracture statistics from field and laboratory observations, including mapping in the ESF; laboratory and field measurements of fracture permeability and permeability variation with stress; and measurements of regional in situ stress at Yucca Mountain. 


\section{BACKGROUND}

Thermal-Mechanical Models For Stress Field Calculation

The first step in the analysis is to estimate the stress field in the rock surrounding emplacement drifts due to excavation of the drifts, construction of a repository and the heating associated with emplacement of waste. There are two fundamentally different methods commonly used to estimate the stress in a fractured rock mass such as that comprising the potential repository horizon. These are the continuum and the discrete element methods.

Continuum Codes:

In this section examples of finite difference and finite element continuum codes are discussed including (FLAC) a numerical finite difference code and ABAQUS a finite element codes. FLAC (Fast Lagrangian Analysis of Continua; sce Itasca Consulting Group, Inc., 1993) is based on solving the dynamic equations of motion, even for quasi-static problems, and the finite element codes directly solve the quasi-static equations of equilibrium. Different constitutive equations and element types can be incorporated in all these codes.

FLAC-3D is a geomechanics modeling code developed originally by Cundall in 1976 and continually upgraded since (Cundall, 1976; Itasca Consulting Group, Inc., 1993; 1996). It has been used for geotechnical problems of tunnel design and slope stability. FLAC-3D is a finite difference code that solves the equations of motion using an explicit solution scheme. The velocities and displacements calculated at each time step are used in the constitutive stress-strain equations to update the stresses for the next time step.

FLAC capabilities include:

(i) A thermal model module that simulates transient heat flow and development of thermal stresses. The thermal model can be coupled to the mechanical stress calculation.

(ii) Failure criteria such as the Mohr-Coulomb criterion (Jaeger and Cook, 1976) or the Hoek-Brown criterion (Hoek and Brown, 1980) can be incorporated into the equilibrium calculations.

(iii) Interface elements that are allowed to undergo tensile separation or Coulomb slip to simulate faults, joints or frictional boundaries. The interface elements can have any spatial orientation in three dimensions. However, these interfaces are treated as impermeable boundaries for fluid flow, and hence the FLAC-3D code cannot solve the coupled thermo-hydro-mechanical problem. 
(iv) Ubiquitous joints (e.g., Itasca Consulting Group, Inc., 1993) can be included as part of the rock mass properties. This feature allows closely spaced joint sets to be modeled in a continuum fashion on a scale much larger than the spacing of individual joints. The ubiquitous joint model assumes a series of weak planes embedded in a Mohr-Coulomb solid. Yield may occur in either the solid or along the slip plane. A joint tensile strength limit is also tested.

A second continuum code that is widely used in the geomechanics field is the ABAQUS code. The ABAQUS code description below is copied from the internet information (http://www.hks.com). More information on ABAQUS is presented by Hibbitt, Karlsson \& Sorensen, Inc., 1994

ABAQUS/Standard is a general purpose finite element analysis program with special emphasis on advanced linear and nonlinear structural engineering and heat transfer applications. ABAQUS/Standard has extensive material, element, and procedure libraries. Material models include plasticity for metals, soils, plastics, foam, composites and concrete, as well as rubber and foam elasticity. Element formulations include beams, shells, and continuum elements allowing finite rotation and finite strain calculations. Analysis procedures include capabilities for statics, dynamics, eigenvalue extraction, soil consolidation, acoustics, piezoelectricity, heat transfer, coupled temperature-displacement, and Joule heating. Very general contact conditions can be specified. A superelement/substructuring capability is also available.

ABAQUS provides the same capabilities to couple heat transport and mechanical equilibrium and to simulate interfaces and closely spaced joints as described above for FLAC.

Continuum models (finite element or finite difference) of fractured bodies can include sufficiently complete descriptions of fracture systems to allow quantitative results of slippage. Dual porosity models can be used when there are no predominant fracture orientations.

\section{Discrete or Distinct Element Codes:}

An alternative treatment of a jointed rock mass is not to see it as a continuum with interfaces, but to see it as a discontinuous system. This alternative viewpoint is the basis of the distinct element method as implemented in UDEC (Universal Distinct Element Code; see Cundall, 1980; Hart and Cundall, 1992; Hart, 1993; Cundall and Hart, 1993) and 3DEC (3-Dimensional Distinct Element Code; see Hart and Cundall, 1992; Hart, 1993; Cundall and Hart, 1993). Four distinguishing characteristics of the distinct element method have been identified by Hart and Cundall (1992):

(i) Discrete bodies within the system can undergo finite displacements and rotations.

(ii) New contacts develop between bodies as the calculation evolves. 
(iii) Contacts are deformable.

(iv) The equations of motion are solved in an explicit time-stepping scheme.

A quasi-static solution scheme can be substituted for (iv) above. As with the continuum codes, Coulomb slip and joint dilation are incorporated into the model. The major reason for using a discrete element rather than continuum model is for situations in which major failure occurs.

Distinct element models were initially designed to model the interaction of independent tumbling grains or bodies. With all the accompanying search and contact at any angle, these algorithms are very tedious and time consuming. Attempts to extend these models into well-ordered, jointed rock masses (where the only movement is a small amount of slippage on a very few fractures) have resulted in a "continuumizing" of the models. The boundaries must be represented in great detail while the search and angle-of-contact algorithms, which define distinct element models, are unnecessary.

Permeability of Fractured Rock.

As stated above, one of the primary areas of coupling between mechanical and hydrologic behavior is via permeability. Permeability changes in fractured rock masses are generally attributed to aperture changes in some of the fractures. Large scale effective permeability of a fractured rock mass is often dominated by the nature of the connections between "piping" segments of high flowing cracks, which can form conduits for most of the flow through a rock mass. Preliminary investigations of the coupled stress-flow mechanism suggest that there is a significant change in permeability due to displacement under shear load. Linear flow experiments on fractures loaded under compression and shear show a change in fracture permeability that is due to a) dilation and b) a production of gouge material as relative motion occurs along the fracture (Mohanty et al., 1994). Quantification of the relative effects of the two mechanisms for permeability change has not been determined. Field results confirm an increase in permeability with shear displacement: Analyses of recorded borehole data in deep crystalline rock show a correlation between sheared fractures and hydraulic conductivity (Barton, Zoback and Moos, 1995). In addition, there is evidence that permeability depends on other parameters as well, such as temperature (Darot, Gueguen and Baratin, 1992). Efforts continue (Ge, 1997) to improve algorithms for fluid flow in rough fractures. Our literature search found that most applicable research focused on the specifics of aperture changes.

Creation of New Fracture Surface. 
Increases in the compressive stress and the temperature of the rock in the near field may also cause the extension of existing fractures and/or the creation of new fractures and this will in-turn alter the permeability. Crack creation and extension can be analyzed using linear elastic fracture mechanics. This theory enjoys wide application to geologic fracture processes. With this theory, tensile crack formation is attributed to the tensile strength of a material, a measurable material property which arises physically from largest flaws in the material, and fracture toughness, another measurable property that quantifies the resistance of a material to crack extension. Theoretically, in a continuum, cracks extend under the slightest opening field stress because any load causes stress at the crack tips to become infinite. Yet physically, the materials are not a continuum on the atomic scale, and energy is required to form new crack surfaces. Fracture toughness and tensile strength vary with material type and also can vary with parameters like temperature, water saturation, and stress history.

There are analogous quantities for fracturing in shear: shear strength and a singular shear stress at the crack tips. Shear strength has meaning along existing fractures (joints) and is, therefore, dependent upon the state of each fracture in the material. If a fracture is open, shear stress near the crack tip determines the amount of out-ofplane bending occurring at the crack tips as the fracture propagates. However, when a joint or fracture exists, the fracture plane is defined and slippage becomes the predominant fracture displacement when the fracture remains closed. In the closed state, surface asperities resist relative motion and this can often be expressed quantitatively as friction. Joints that have been stable for a long time tend to form a cement-like bond. The measured shear strength of a material is the level of shear stress needed to break this bond. Relative motion along a fracture typically occurs as stick-slip motion.

We are interested in drift excavation loads that can cause slippage along criticallyoriented fractures. We are also interested in the steepness of the heater-induced thermal front and the effects of the generated local thermal stresses on fracture slippage, and any reverse slippage as the thermal pulse diffuses.

\section{Simulation of Coupled Thermal-Mechanical-Hydrologic Processes}

The DEvelopment of COupled models and their VALidation against EXperiments (DECOVALEX) program (Jing, L., C. F. Tsang, and O. Stephansson, 1995) was designed for the evaluation of computer codes capable of simulating coupled thermal-mechanical-hydrological processes as might occur in a nuclear waste repository. The program did not emphasize permeability changes specifically, but did address heating and excavation effects on fractures, which is of direct importance in determining changes in permeability. Consequently, some results of these investigations are pertinent here. 
Test case 1 of the DECOVALEX program (Rosengren and Christianson, 1995) was designed to gain insight into the coupled behavior of a fracture under conditions of compression and shear stress. This study included both experimental and modeling components. In the experimental component, the flow rate through a compressed and sheared fracture was used to estimate the change in aperture of a fracture. The distinct element model UDEC (Cundall, 1980; Hart and Cundall, 1992) was then used to simulate the experiment. Qualitative arguments about the experiment are used to explain how quantities, such as aperture, are determined and to explain differences between prediction and simulation. Aperture estimations are further complicated because the applicability of the cubic law for flow in a fracture deteriorates as the normal stress and fracture roughness increase (Gale and Raven, 1980). Shortcomings of the joint models in UDEC during cyclic and reverse shearing are mentioned here; they are discussed in more detail in a Nuclear Regulatory Commission-sponsored study (Hsiung et al., 1994). In particular, the three rock joint models (MohrCoulomb, Barton-Bandis, and Continuously-Yielding) that are used in UDEC demonstrate deficiencies in the prediction of joint shear and dilation behavior during reverse shearing, which is likely to result from earthquakes or the thermal cycle of a high-level waste repository. Consequently, these three models can overestimate the stability around excavations and can predict erroneous near-field flow patterns including preferential pathways for water and gas. These considerations are of great importance to us. In general, the rock-joint models in computer codes under consideration for seismic design do not correctly model the expected pseudostatic cyclic joint behavior. Consequently, development of a new rock-joint behavior model is underway (Ahola et al., 1995). This study also illustrated the difficulty of performing meaningful shear tests on fractures using laboratory-sized models.

Test case 2 of the DECOVALEX program (Borgesson and Hernelind, 1995a) employed the finite element model ABAQUS for thermo-mechanical modeling of a fractured rock volume that was affected by excavation and heating during a large scale test in a French uranium mine. The calculations included thermal distributions from the heating and cooling periods of the test and associated mechanical strains as well as strains from the excavation process. Temperatures and floor displacements compared well between model and test but attempts to calculate fracture displacements and effects were inadequate. Fracture displacements are of major interest to us because they are paramount in defining changes in fracture permeability. Consequently, the model, as used in this test, is deficient for our needs because of our requirement for accurate predictions of fracture displacement.

In another study a large scale laboratory test of heating and flow in an artificial deposition hole, named BIG-BEN and designed for testing the Japanese concept for nuclear waste disposal, was simulated with a version of ABAQUS (Hibbitt, Karlsson \& Sorensen, Inc., 1994) that included vapor flow processes (Borgesson and Hernelind, 1995b). The test was performed on a water-unsaturated buffer material. The calculations resulted in a prediction of void ratio, temperature, water saturation, pore pressure and effective stress. The calculations were coupled thermo- 
hydro-mechanical; the hydraulic and thermal results compared well with the . experiment but the prediction of mechanical response did not. The threedimensional finite element model THAMES underestimated the experimental measurements of temperature in the buffer material (Ahola et al., 1995).

FLAC 2-D (Itasca Consulting Group, Inc., 1993) was used to model heat and water flow through a $50 \mathrm{~m} \times 50 \mathrm{~m}$ block of fractured granite (Israelsson, 1995). Stressinduced permeability changes were limited to one order of magnitude and fractures were taken to be randomly oriented, thus allowing the continuum approach in FLAC. Zhang and Sanderson (1996) employed a distinct element code to illustrate why rock masses with one or more systematic sets of oriented fractures should not be represented as an equivalent porous medium.

Peer reviewers of the Coupled Thermal-Mechanical-Hydrological Program at the Center for Nuclear Waste Regulatory Analyses made recommendations for future research (Ahola et al., 1996): 1) Heating should be incorporated into single rock-joint stress tests. 2) More research on thermal-hydrological processes such as vaporization, migration, condensation, and capillary recirculation should have a high priority. 3) Confirm that the primary mode of heat transfer within the repository is conduction. 4) Re-evaluate the design of the shear box used for mechanical-hydrological tests of single joints. 5) Conduct selected large-scale field tests to define processes that might have been missed with laboratory experiments and modeling efforts.

\section{Comparison of 2-D and 3-D Models}

Simulations of the thermal-mechanical behavior of the heat-up portion of the Large Block Test (Lin et al., 1995, 1996) were conducted with 2-d and 3-d models by Blair, Berge and Wang (1996), using FLAC (Itasca Consulting Group, Inc., 1993) for 2-d modeling and ABAQUS (Hibbitt, Karlsson \& Sorensen, Inc., 1994) for 3-d modeling. The plane-strain assumption in the $2-d$ model is overly restrictive in this case because the block is limited in the 3rd dimension and is stress-free at those boundaries, while plane strain assumes infinite extent in the 3rd dimension. (It should be noted that the plane-strain assumption of $2-d$ models is less restrictive underground, where extent of the medium in the 3rd dimension can be assumed to be infinite.) It was found that temperature predictions in the block were similar with both the 2-d and 3-d models, but differences in predicted stresses became more pronounced near the edges of the block.

The general geometry of a linear series of heaters in a continuum can be represented in two dimensions if one takes a cross-section through the center of the heater drift, perpendicular to the drift, while restricting results to a radial distance which is a fraction of the length of the heater drift. If, however, regions of interest are farther from the drift or in the region of the ends of the drift, a three-dimensional analysis is required. Further restrictions apply when oriented fracture sets are present. 
Because of the planar nature of each fracture, 2-d analysis can capture slipping . phenomena on favorably-oriented fracture systems. However, fracture systems at an angle to the array of heaters (or the drift axis) require a 3 -d analysis for completeness.

\section{SUGGESTED PROCEDURE}

The suggested approach for estimating changes in fracture permeability is similar to one used by Case and Kelsall (1987). They estimated changes in rock mass permeability as a function of radius due to excavation of vertical shafts. Their procedure included estimating lower and upper bounds by using input parameters bounds known to decrease or enhance permeability changes, respectively. Thus, they obtained a lower-bound estimate of the increase in rock mass permeability by using an upper bound for the strength properties, a lower bound for the in situ stresses, and a lower bound for the variation of permeability with stress.

The suggested procedural steps recommended in this report are as follows:

1. Calculate stress changes from a mechanical model for construction-induced effects and a thermal stress model for subsequent heating from waste canisters. Regional stresses are incorporated as far-field boundary conditions. The stress model can be finite difference or finite element (e.g., FLAC, ABAQUS) or it can be distinct element (e.g., UDEC).

2. Determine if stress changes (a) open or extend pre-existing fractures and/or (b) create new fractures. Pre-existing fracture statistics are obtained from previous mapping of the ESF. The criteria for initiation, opening, or extension of fractures can be based either on a fracture mechanics model, a stochastic fracturing model (Blair, 1994), or on the Coulomb strength for shear stress (Barton et al., 1996) and tensile strength for normal stress.

3. Estimate permeability change of rock mass. The overall change of fracture permeability of the rock mass can be based on stochastic fracture models such as FracMan (Golder and Associates, Inc., 1993) coupled with either a fracture-only flow model or on a double porosity flow model (e.g., Preuss and Narasimhan, 1985), Lattice-Boltzmann percolation models (e.g., Rothman, 1988), or network theory. The estimated changes in the distribution function of transmissivity of individual fractures from the effects of stress or temperature change are based on theory, and laboratory and field measurements.

These three procedural steps are discussed individually in the following sections.

Determination of Hydraulically Conducting Fractures

The fracture permeability of the rock mass following excavation due to construction or following heating due to radioactive waste requires determining the network of 
hydraulically conducting fractures and their conductivities. Not all fractures, . whether pre-existing or created as a result of repository activity, are hydraulically conducting. Barton et al. $(1995,1996)$ established a correlation between hydraulically conducting fractures and their being in a critical stress state from studies of the Dixie Valley, Nevada, geothermal reservoir and of a proposed low-level nuclear waste disposal facility in central North Carolina. The critical stress state can be either a tensile stress exceeding a critical value or it can be the Coulomb failure criterion of the ratio of shear-to-normal stress exceeding about 0.6 . Thus, the subset of hydraulically conducting fractures is obtained from a consideration of the stress state of each fracture.

Permeability Change of Rock Mass

The geometry of a discrete fracture system and the transmissivity of individual fractures together determine the permeability of the rock mass. The FracMan code of Golder Associates, Inc. (1993) simulates fluid flow in a three dimensional rock mass through realizations of distribution statistics of the fracture system. The code permits several models of fracture system geometry such as the modified Baecher model (Baecher, Lanney, and Einstein, 1977) in which fractures, whose lengths have a log normal distribution, terminate where intersecting other fractures. Other models are the Levy-Lee clustering model, the nearest neighbor model, and the War Zone model (Golder Associates, Inc., 1993). These models are constrained by data such as fracture traces mapped on the wall of the ESF (e.g., Barr, Borns, and Fridrich, 1996). FracMan accounts for the effects of geometrical bias of sampling a tunnel, borehole, or outcrop surfaces.

The transmissivities of individual fractures are needed in addition to the fracture system geometry (lengths and orientations). The transmissivities are also treated as a statistical distribution function, based on laboratory and field data and theoretical understanding of flow in individual fractures. Laboratory data on the effects of normal stress have been obtained by Raven and Gale (1985) and are being obtained in laboratory tests on $0.5 \mathrm{~m}$ scale blocks of Topopah Spring Tuff under a separate section of this task. The effects of shear stress are less well known, and bounds must be estimated. The influence of temperature is also sketchy. It appears as if a decrease in transmissivity due to thermal expansion into fractures is greater than an increase due to thermal cracking of grains in the matrix. On-going laboratory tests on small blocks at the $0.5 \mathrm{~m}$ scale (e.g., Blair and Berge, 1997) will provide more information about temperature effects on permeability for individual fractures.

The final step to estimating permeability of the rock mass is to use an option in FracMan to prepare the input file for the Golder Associates, Inc. three-dimensional flow code MAFIC-3D (Matrix Fracture Interaction Code) (Golder Associates, Inc., 1990) based on the fracture system FracMan has generated. 


\section{INPUT DATA FOR MODFIS}

A three-step procedure for estimating bounds on permeability changes due to stress changes was described above. Each step requires some input data for the modeling. The first step, calculating stress changes due to mechanical or thermal loads, requires information about the original in situ stresses, mechanical properties, and thermal properties of the rock being modeled. The second step, determining how stresses affect fractures, requires statistical information about the original numbers and sizes of the fractures, and data on rock strength and mechanical properties of fractures. The third step, estimating permeability changes, requires either assumptions or else additional information about the permeability of individual fractures under different stress and temperature conditions. Field measurements of in situ permeability for networks of fractures would also be useful. The following sections discuss these input parameters, both in terms of what input parameters are required, and what observations are available for different parameters.

\section{Mechanical Properties of Tuff and Fractures}

The modeling codes discussed in the previous sections require various input parameters that describe the mechanical properties of the rock being modeled, which is Topopah Spring tuff for our modeling. The number and type of parameters used to describe the mechanical properties of the fractured tuff depend on what constitutive model is being used to describe how the rock responds to stress. An unfractured rock mass would be represented as a homogeneous, isotropic elastic medium. The mechanical response of such a medium is described completely using only three parameters, the density and two independent elastic moduli (where these moduli can be determined from any two of the mechanical properties typically measured in the laboratory or the ficld, e.g., bulk modulus, shear modulus, Young's modulus, Poisson's ratio, compressional wave velocity, shear wave velocity). The effects of the fractures on rock mass mechanical behavior can be included in several ways, by relaxing one of the assumptions (i.e., homogeneity, isotropy, purely elastic). Relaxing any of these assumptions means that additional parameters are required to describe the fractured rock.

The simplest way to include the effects of the fractures on the mechanical properties would be to assume that the fractured rock is isotropic and elastic, and that the fractured rock is a homogeneous effective medium with elastic properties that can be calculated from known elastic properties of the unfractured rock and known fracture sizes and concentrations, using effective medium theories (e.g., Berryman, 1995). This approach requires a minimum of four parameters: the density and two elastic moduli for the unfractured rock, and a parameter describing the amount of fractures present (number, concentration, or relative volume) in a given amount of rock. Some of the more sophisticated effective medium theories require an additional parameter that describes the shape or aperture of typical fractures. Although this approach is a good way to find mechanical properties of the fractured 
rock, information about fracture orientation and connection is not used, and some of the effective medium theories break down for very high concentrations of thin fractures. This approach is probably best for the case of randomly-oriented fractures that are moderately small in size or concentration. Although it may not be appropriate for describing the large-scale fractures that initially govern fluid flow, this approach may be a good way to model thermally-induced microcracks in the tuff.

The simplest way to incorporate information about fracture orientation would be to assume the fractured rock is elastic and effectively homogeneous, and to relax the assumption of isotropy. For an elastic but anisotropic constitutive model, additional elastic moduli would be required, e.g. three more for the case of transverse isotropy, up to a maximum of 21 independent elastic moduli for the most general case of anisotropy (Auld, 1973). There is some evidence from laboratory measurements that the Topopah Spring tuff may be slightly anisotropic due to horizontal foliation (Martin et al., 1992; Blair and Berge, 1997), and the presence of a dominant set of subvertical fractures striking approximately to the north as mapped in the Large Block (Lin and Ramirez, 1996) suggests that the tuff may be anisotropic with orthorhombic symmetry. Since the Large Block also contains many other fractures striking in different directions, the anisotropy may be weak compared to the variations in rock properties due to heterogeneity of the Topopah Spring tuff. At this time, we do not have sufficiently detailed laboratory or field measurements available for determining all the independent elastic moduli that would be required to quantify anisotropy in the Topopah Spring tuff (Blair and Berge, 1997). For the purposes of our modeling, we will initially assume the rock is isotropic.

An isotropic, elastic, but inhomogeneous model can be used by assuming the tuff is homogeneous except for a few fractures that can be represented in the computer model as interfaces where displacement is allowed. Several of the modeling codes described in the previous sections (e.g., FLAC, ABAQUS) allow such interfaces to be defined. Parameters required for such a model include density and two elastic moduli for the tuff itself, and fracture length, orientation, and strength information for each interface. Information about fracture orientation is used in this approach, but it is impractical to incorporate many interfaces in the model. This approach is best for representing a few major fractures, those that are considered most significant for fluid flow. It is complementary to the effective medium theory approach described above, and we expect to use both techniques in our modeling.

If the assumption of purely elastic behavior is dropped and the ubiquitous joint model is used to describe the fractured rock (e.g., Blair, Berge, and Wang, 1996; Arulmoli and St. John, 1987), necessary additional parameters (besides density and two elastic moduli for the unfractured rock) include the cohesion, dilation angle, tension limit, and internal angle of friction for the tuff, as well as joint angle, joint cohesion, joint tension, and joint friction angle for the fracture set represented in the model. The main limitation of this approach is that it assumes that a high concentration of parallel fractures is controlling the behavior of the rock mass. Note 
that this approach and the effective medium theory and interface approaches are. complementary, and so we expect to use all three approaches in our modeling.

Information about available measured mechanical properties of Topopah Spring tuff and mechanical properties of fractures in the tuff (Table 1) is described in detail in Blair and Berge (1996). In summary, this information comes from laboratory measurements on cores at the scale of a few cm (e.g., Price, Connolly, and Keil, 1987; Martin et al., 1994; Blair et al,, 1996) and on small blocks of tuff at the scale of about $0.5 \mathrm{~m}$ (Blair and Berge, 1997), and field experiments at the scale of a few m (e.g., Zimmerman et al., 1986). Observations include elastic moduli and strength data for the tuff under different temperature conditions (e.g., Price, Connolly, and Keil, 1987; Blair and Berge, 1997) as well as mechanical properties of the fractures at laboratory scales of a few $\mathrm{cm}$ to a few tens of $\mathrm{cm}$ (e.g., Olsson and Brown, 1994; Blair and Berge, 1997). Strength and moduli for the tuff are known to decrease with temperature (Price, Connolly, and Kiel, 1987; Blair and Berge, 1997) and with sample size (Price, 1986; Blair and Berge, 1997). The laboratory measurements may overestimate strengths and stiffnesses for the fractured tuff at larger scales, since the laboratory measurements cannot incorporate the effects of multiple fractures that are longer or more widely spaced than the laboratory sample size. On the other hand, laboratory tests provide information not available from field data (e.g., Blair et al., 1996). At this time, no mechanical properties observations are available from the Large Block Test, and only preliminary data at ambient temperatures are available for the field experiments in the ESF. We will incorporate new field data in our modeling as they become available.

\section{Thermal Properties of Topopah Spring Tuff}

Our modeling requires the following parameters to describe the thermal properties of the Topopah Spring tuff: thermal conductivity, specific heat or thermal capacitance, and thermal expansion coefficient, for temperatures between about 25 deg. $C$ and 250 deg. C. These parameters are discussed in detail in Blair and Berge (1996) and summarized in TABLE 2. Observations are mainly from core samples at the scale of a few $\mathrm{cm}$. We will incorporate any new information from field-scale tests as it becomes available. The thermal conductivity was measured in situ by Nimick (1990). Thermal conductivity and thermal capacitance were measured in the laboratory by TRW Environmental Safety Systems Inc. (1996), and measured values for core samples are also found in the Reference Information Base (RIB) (DOE, 1994). Measured values for each of these two thermal parameters vary by less than $10 \%$ over a wide range of temperatures. The thermal expansion coefficient, however, increases with temperature (Martin et al., 1996). Data from the RIB (DOE, 1994) show this parameter increasing by a factor of 5 or more for measurements made at temperatures of about $250 \mathrm{deg}$. C, compared to measurements made at about $25 \mathrm{deg}$. C. Values in the RIB show similar increases with temperature (DOE, 1994). In our modeling, we will include a sensitivity study for this parameter to see how different values affect our results. 


\section{Fracture Statistics}

As discussed above, the required information about the fracture statistics includes the lengths, orientations, concentrations, and apertures of the fractures. This information is available at various scales, including descriptions of cracks in tuff cores at the cm scale (e.g., Blair et al., 1996) and observations of cracks and vugs in small blocks of tuff at the $0.5 \mathrm{~m}$ scale (Blair and Berge, 1997), descriptions of fractures in core recovered from boreholes (e.g., Lin, Hardy, and Bauer, 1993), detailed maps of fractures in the Large Block (Lin and Ramirez, 1996; Lin et al., 1996), and information about fractures mapped in the ESF (Barr, Borns, and Fridrich, 1996). Fracture statistics are discussed in detail in Lin and Ramirez (1996). In summary, the fracture mapping from the Large Block and the ESF found subvertical fractures striking predominantly to the north (Lin and Ramirez, 1996), with typical fracture concentrations of about 0.5 to 0.75 fracture/foot for the Large Block and 1 fracture/foot (3-4 fractures/m) for the ESF (Lin and Ramirez, 1996). The orientation data are consistent with earlier measurements from boreholes (Lin, Hardy, and Bauer, 1993). Subhorizontal fractures were also mapped in the ESF and for the Large Block, but the concentrations were lower than for the vertical fractures. Fracture apertures observed for fractures mapped on the surface of the Large Block varied from hairline $(<0.5 \mathrm{~mm})$ to about $2 \mathrm{~cm}$ and borehole camera footage from vertical holes drilled in the Large Block showed large openings (apertures of several $\mathrm{cm}$ ) for some vertical fractures in areas near the base of the block (pers. commun., W. Lin, 1995). These observations do not provide information about which fractures control the fluid flow. We also do not have detailed information about the fracture surface morphology that could be used to infer which fractures are tensile and which originated from shearing (e.g., Einstein and Dershowitz, 1990). Additional fracture information from the ESF and Large Block field experiments will be incorporated in our modeling as it becomes available.

\section{Permeability of Fractures}

Determining permeability variation with stress requires making assumptions or else using information about in situ permeability before excavation or waste emplacement. It is not possible to obtain complete information about the permeability for the undisturbed site, since the boreholes drilled for permeability measurements affect the permeability. Nevertheless, field measurements provide an estimate of the large-scale permeability. For our modeling, we need information about permeability for individual fractures, in addition to field data describing permeability for networks of fractures. Thus we are also interested in laboratory measurements of permeability in single fractures.

Air permeability data from air injection tests performed in the Large Block and as part of the G-Tunnel tests showed that permeability in the Topopah Spring tuff at the scale of a few meters varies over about 5 orders of magnitude due to 
heterogeneity of the fractured tuff (Lin et al., 1995; Lin and Ramirez, 1996). LeCain and Walker (1994) found that, because of fractures, the air permeabilities measured in a borehole in Yucca Mountain were several orders of magnitude larger than permeabilities measured in tuff cores. In situ values for Topopah Spring tuff were about 1.1 to $12.0 \times 10^{-13} \mathrm{~m}^{2}(.11$ to $1.2 \mathrm{D})$ (LeCain and Walker, 1994). In the Large Block, measured air permeability values were about $10^{-16} \mathrm{~m}^{2}$ to $7 \times 10^{-12} \mathrm{~m}^{2}(0.1 \mathrm{mD}$ to 7 D), with the highest values being measured near the bottom of the block where large, open subvertical fractures intersect the vertical boreholes (Lin and Ramirez, 1996). The G-Tunnel test data showed that permeability changed after the rock was heated. Regions where permeabilities were low before heating developed microcracks and the permeabilities increased.by about an order of magnitude after the heating (Lin and Ramirez, 1996).

Lin and Roberts (1996) present laboratory measurements of water permeability in cores of Topopah Spring tuff for intact cores and cores containing single fractures. They found that for the intact cores, water permeability was independent of temperature, time, and dehydration/rehydration cycles, for temperatures between about 20 deg. $C$ and about 140 deg. $C$ at a confining pressure of about $5 \mathrm{MPa}$. Permeability values for water in the intact core samples were found to be between about 0.1 and $0.7 \times 10^{-18} \mathrm{~m}^{2}\left(0.1\right.$ to $\left.0.7 \times 10^{-6} \mathrm{D}\right)$ (Lin and Roberts, 1996).

Lin and Roberts (1996) found that permeabilities of fractured tuff samples responded to elevated temperature in a fundamentally different way. They conducted several experiments in which temperature and confining pressure were varied independently, and also studied fracture healing after flowing water and steam through a fracture during heating. For confining pressures between 1 and $5 \mathrm{MPa}$ and a constant pore pressure of $0.5 \mathrm{MPa}$, the permeability at room temperature for the core containing a single fracture went from about $18 \times 10^{-15} \mathrm{~m}^{2}(18 \mathrm{mD})$ down to about $11 \times 10^{-15} \mathrm{~m}^{2}(11 \mathrm{mD})$, and recovered to the initial value when the pressure was released (Lin and Roberts, 1996). This indicates that the $5 \mathrm{MPa}$ pressure did not cause any inelastic deformation of the fracture surfaces. Cycling the temperature from about 25 deg. $C$ to $150 \mathrm{deg}$. $C$ and back to 25 deg. $C$ at constant confining pressures of $1,2,3$, and $5 \mathrm{MPa}$ caused the permeability to drop, with the lowest value measured being about $2 \times 10^{-15} \mathrm{~m}^{2}(2 \mathrm{mD})$ at a confining pressure of $5 \mathrm{MPa}$ (Lin and Roberts, 1996). Most of the drop occurred during the first heating cycle, at $1 \mathrm{MPa}$ confining stress. The permeability did not recover when the stress was reduced at the end of the experiment. During this experiment, the decrease in permeability corresponded to possible deposition of $\mathrm{Si}$ on the fracture surfaces.

The laboratory data give us approximate values to assign to individual fractures in our modeling, and provide guidance for how permeability varies with temperature and stress for individual fractures. The field data provide information about in situ permeability for networks of fractures, and an indication of how much change to expect in the large-scale permeability as a result of heating and microcracking. As additional laboratory and field data become available, they will be incorporated in 
our modeling. In particular, a new experiment in which water flow through a single fracture in a small block of tuff (at the $0.5 \mathrm{~m}$ scale) is being measured as a function of temperature and stress, is expected to provide useful information for our modeling. On-going thermal tests in the ESF and the Large Block Test are also expected to provide additional field observations of permeability changes due to heating.

In Situ Stress

Information about in situ stress is discussed in Blair and Berge (1996). Stock et al. $(1984,1985)$ measured in situ stress values for the potential repository horizon in Yucca Mountain in drill holes. They found that the vertical stress has an average value of about $7 \mathrm{MPa}$, with a range of values from 5 to $10 \mathrm{MPa}$. The minimum horizontal stress was found to have a bearing of about $N 57$ deg. W (+ or -8 deg.), and the bearing for the maximum horizontal stress was found to be about $N 32$ deg. $\mathrm{E}$ (+ or -8 deg.).

The ratio of horizontal stress to vertical stress had an average value of about 0.5 or 0.6 and a range of about 0.3 to 0.8 or 0.3 to 1.0 for the minimum or maximum horizontal stress, respectively. These values provide the in situ stress information that we need for our modeling.

\section{SUMMARY AND CONCLUSIONS}

A three-step procedure is proposed to estimate permeability due to constructioninduced stress changes and to heating. Firstly, a numerical stress model (FLAC or $A B A Q U S$ ) is used to calculate stress changes associated with construction or heating. Secondly, shear and normal stress criteria for creation of new fractures and/or opening of pre-existing fractures are applied, and permeability changes of individual fractures or sets of fractures are estimated. The literature review shows that permeabilities are sensitive to changes in shear and normal stress, but little direct experimental data quantify the effect of stress changes or heating on permeability changes. Predictions of permeability are based, therefore, indirectly on the effects of stress on fracture aperture, and a cubic law relation between the aperture and transmissivity. It is important to recognize that permeability of fractured rock masses is often dominated by preferential flow paths. Thirdly, a network flow model (FracMan, MAFIC) is applied to estimate the change in permeability of the rock mass. This procedure is recommended because the comprehensive literature review shows it to be consistent with availability of laboratory and field data and numerical models.

The choice of the proposed continuum modeling codes FLAC-3D and ABAQUS builds on results from the DECOVALEX program, which evaluated the performance of these codes in simulating experimental and field data, which include coupled thermal-mechanical-hydrological processes. 
The input data required by the stress modeling codes include the in situ stress, . mechanical and thermal properties of tuff, mechanical properties of fractures, and fracture statistics. These data are available for the repository site. Available information about permeability can also be incorporated. 
Table 1. Mechanical Properties of Topopah Spring Tuff and Fractures.

\begin{tabular}{|c|c|c|c|c|}
\hline Property & Conditions & Value & Source & Comments \\
\hline porosity & $\begin{array}{l}\text { ambient temp., } \\
\text { press. }\end{array}$ & $9-28 \%$ & $\begin{array}{l}\text { Lin \& Roberts, } \\
1996\end{array}$ & $\begin{array}{l}\text { lab. meas. on } \\
\text { cores, small } \\
\text { blocks }\end{array}$ \\
\hline bulk density & " & $\begin{array}{r}2280-2360 \\
\mathrm{~kg} / \mathrm{m}^{3}\end{array}$ & $\begin{array}{l}\text { Blair et al., } \\
1996\end{array}$ & $\begin{array}{l}\text { lab. meas. on } \\
\text { dry cores }\end{array}$ \\
\hline peak strength & $\begin{array}{l}25^{\circ} \mathrm{C} \text {, unconf. } \\
\text { uniax. compress. }\end{array}$ & $\begin{array}{l}155 \pm 59 \mathrm{MPa} \\
154+36 \mathrm{MPa}\end{array}$ & $\begin{array}{l}\text { Price, } 1986 \\
\text { Blair et al., } \\
1996\end{array}$ & $\begin{array}{l}\text { lab. tests on } \\
\text { cores }\end{array}$ \\
\hline " & " & $139 \pm 73 \mathrm{MPa}$ & $"$ & $\begin{array}{l}\text { lab. tests on } \\
\text { irrad. cores }\end{array}$ \\
\hline " & $\begin{array}{l}22^{\circ} \mathrm{C} \text {, unconf. } \\
\text { uniax. compress. }\end{array}$ & $68-102 \mathrm{MPa}$ & $\begin{array}{l}\text { Price, } \\
\text { Connolly, \& } \\
\text { Keil, 1987 }\end{array}$ & $\begin{array}{l}\text { lab. tests on } \\
\text { dry \& sat. } \\
\text { cores }\end{array}$ \\
\hline " & $\begin{array}{l}150^{\circ} \mathrm{C} \text {, unconf. } \\
\text { uniax. compress. }\end{array}$ & 89-136 MPa & 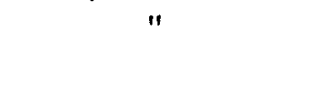 & $\begin{array}{l}\text { lab. tests on } \\
\text { sat. cores }\end{array}$ \\
\hline " & $\begin{array}{l}22^{\circ} \mathrm{C}, 5 \mathrm{MPa} \text { conf. } \\
\text { press. }\end{array}$ & $155-220 \mathrm{MPa}$ & $"$ & " \\
\hline$"$ & $\begin{array}{l}150^{\circ} \mathrm{C}, 5 \mathrm{MPa} \\
\text { conf press. }\end{array}$ & $48-155 \mathrm{MPa}$ & " & " \\
\hline " & $\begin{array}{l}22^{\circ} \mathrm{C}, 10 \mathrm{MPa} \\
\text { conf. press. }\end{array}$ & $152-305 \mathrm{MPa}$ & " & $"$ \\
\hline $\begin{array}{l}\text { indirect tensile } \\
\text { strength }\end{array}$ & ambient temp. & $4-16 \mathrm{MPa}$ & $\begin{array}{l}\text { Martin et al., } \\
1994 ; 1995\end{array}$ & $\begin{array}{l}\text { Brazil tests on } \\
\text { sat. cores }\end{array}$ \\
\hline $\begin{array}{l}\text { Young's } \\
\text { modulus }\end{array}$ & $\begin{array}{l}25^{\circ} \mathrm{C} \text {, unconf. } \\
\text { uniax. compress. }\end{array}$ & $33 \pm 5 \mathrm{GPa}$ & DOE, 1994 & $\begin{array}{l}\text { lab. tests on } \\
\text { cores }\end{array}$ \\
\hline & $\begin{array}{l}25^{\circ} \mathrm{C} \text {, unconf. } \\
\text { uniax. compress. }\end{array}$ & $38-40 \mathrm{GPa}$ & $\begin{array}{l}\text { Price, Martin, } \\
\text { \& Haupt, } 1994\end{array}$ & $"$ \\
\hline$"$ & $\begin{array}{l}25^{\circ} \mathrm{C} \text {, unconf. } \\
\text { uniax. compress. }\end{array}$ & $25 \pm 3 \mathrm{GPa}$ & $\begin{array}{l}\text { Blair et al., } \\
1996\end{array}$ & $"$ \\
\hline " & $\begin{array}{l}25^{\circ} \mathrm{C} \text {, unconf. } \\
\text { uniax. compress. }\end{array}$ & $23 \pm 5 \mathrm{GPa}$ & $"$ & $\begin{array}{l}\text { lab. tests on } \\
\text { irrad. cores }\end{array}$ \\
\hline " & $\begin{array}{l}22^{\circ} \mathrm{C} \text {, unconf. } \\
\text { uniax. compress. }\end{array}$ & $27-46 \mathrm{GPa}$ & $\begin{array}{l}\text { Price, } \\
\text { Connolly, \& } \\
\text { Keil, } 1987\end{array}$ & $\begin{array}{l}\text { lab. tests on } \\
\text { dry \& sat. } \\
\text { cores }\end{array}$ \\
\hline " & $\begin{array}{l}150^{\circ} \mathrm{C} \text {, unconf. } \\
\text { uniax. compress. }\end{array}$ & 28-33 GPa & $"$ & $\begin{array}{l}\text { lab. tests on } \\
\text { sat. cores }\end{array}$ \\
\hline$"$ & $\begin{array}{l}22^{\circ} \mathrm{C}, 5 \mathrm{MPa} \text { conf. } \\
\text { press. }\end{array}$ & $36-41 \mathrm{GPa}$ & $"$ & " \\
\hline$"$ & $\begin{array}{l}150^{\circ} \mathrm{C}, 5 \mathrm{MPa} \\
\text { conf. press. }\end{array}$ & $16-36 \mathrm{GPa}$ & $"$ & " \\
\hline$"$ & $\begin{array}{l}22^{\circ} \mathrm{C}, 10 \mathrm{MPa} \\
\text { conf. press. }\end{array}$ & $33-41 \mathrm{GPa}$ & " & $"$ \\
\hline
\end{tabular}




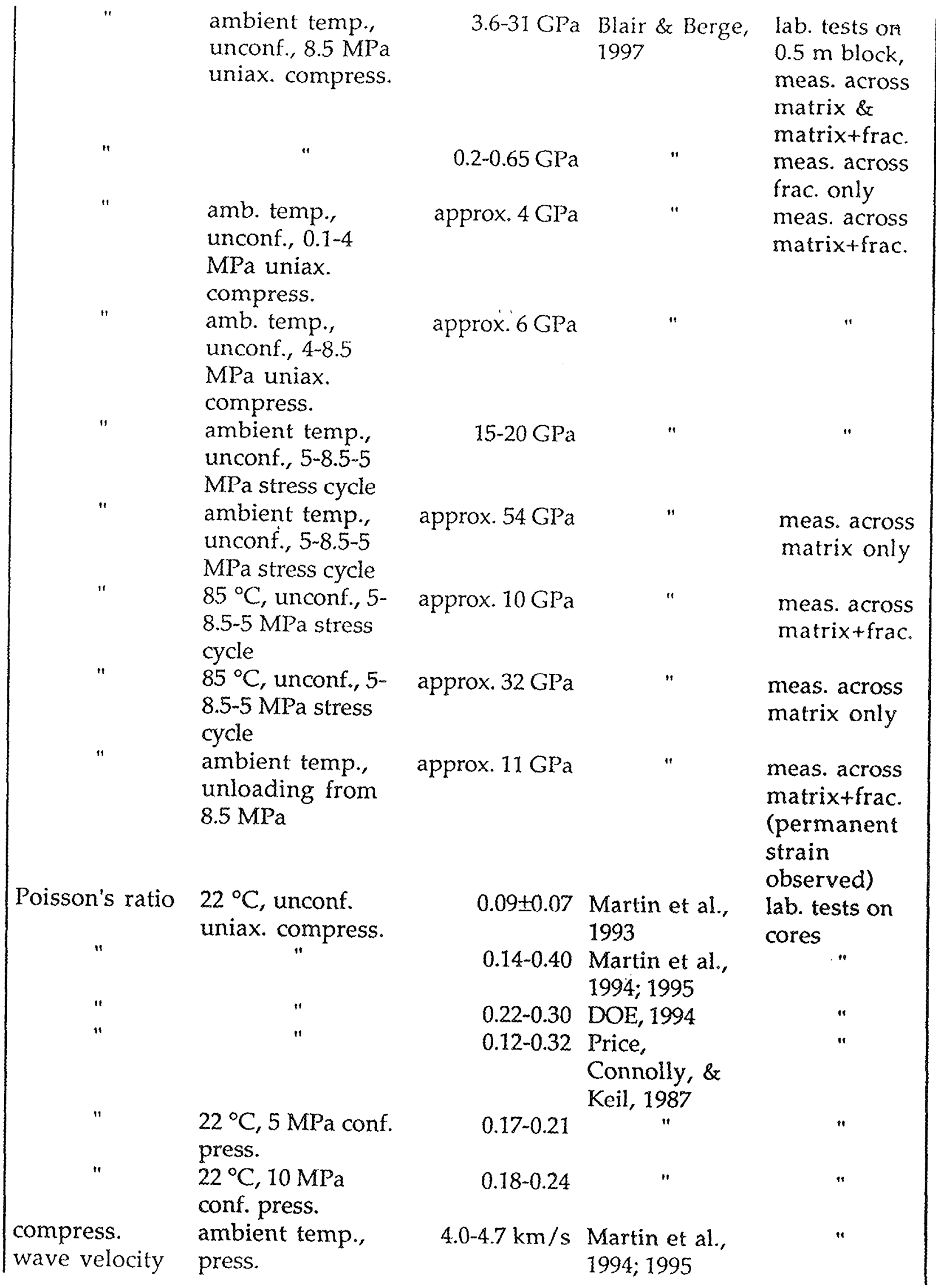




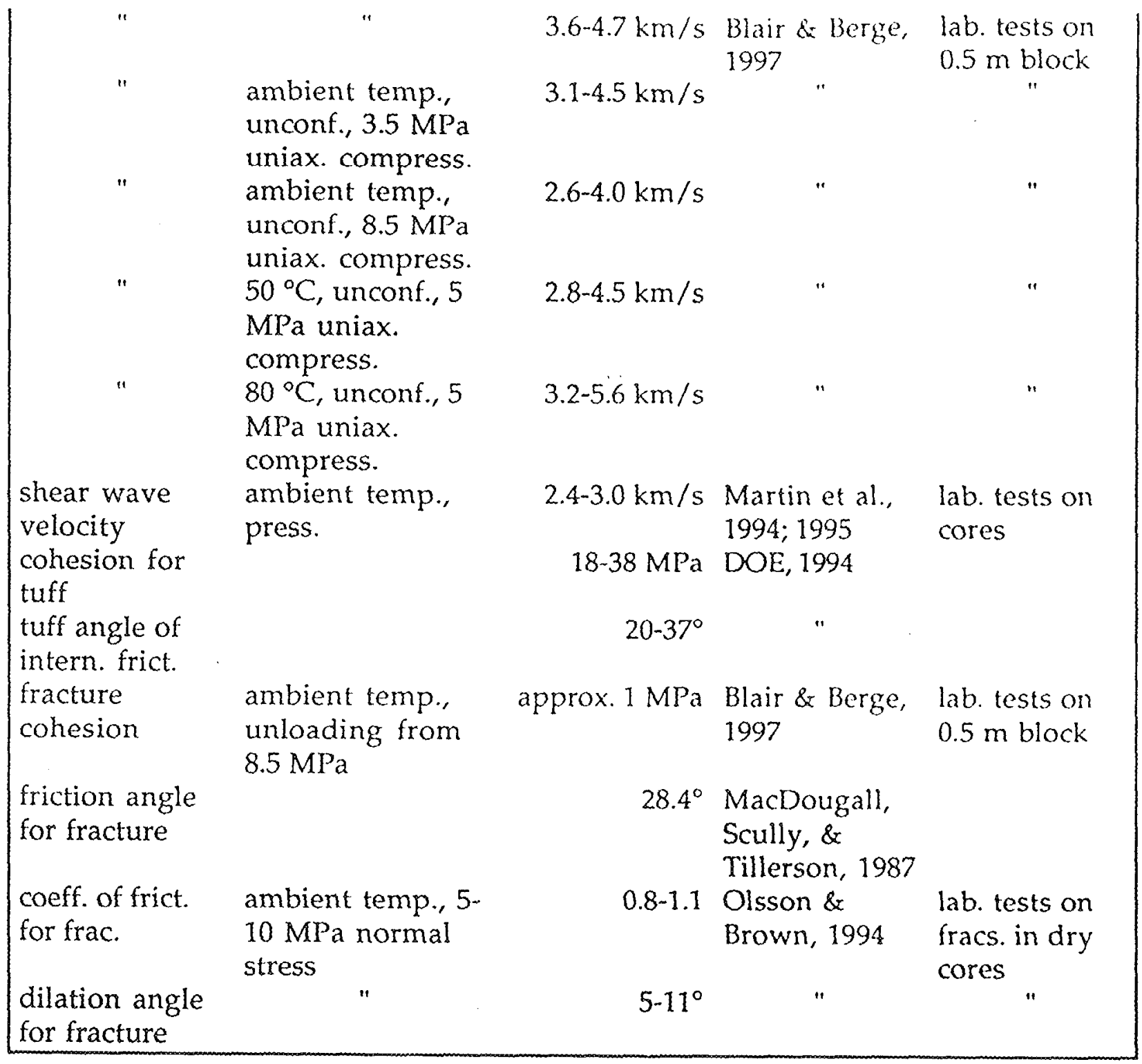


Table 2. Thermal Properties of Topopah Spring Tuff.

\begin{tabular}{|c|c|c|c|c|}
\hline Property & Conditions & Value & Source & Comments \\
\hline $\begin{array}{l}\text { thermal } \\
\text { conductivity }\end{array}$ & in situ & $2.1 \pm 0.2 \mathrm{~W} / \mathrm{m}-{ }^{\circ} \mathrm{K}$ & Nimick, 1990 & in situ tests \\
\hline specific heat & $30-290^{\circ} \mathrm{C}$ & $1.67 \pm 0.15 \mathrm{~W} / \mathrm{m}-^{\circ} \mathrm{K}$ & $\begin{array}{l}\text { TRW Env. Safe. } \\
\text { Sys. Inc., } 1996 \\
\text { DOE } 1994\end{array}$ & $\begin{array}{l}\text { lab. tests on } \\
\text { rock from FSF }\end{array}$ \\
\hline & $25-300^{\circ} \mathrm{C}$ & $928 \mathrm{~J} / \mathrm{kg}{ }^{\circ} \mathrm{K}$ & $\begin{array}{l}\text { TRW Env. Safe. } \\
\text { Sys. Inc., } 1996\end{array}$ & $\begin{array}{l}\text { lab. tests on } \\
\text { rock from ESF }\end{array}$ \\
\hline $\begin{array}{l}\text { thermal } \\
\text { capacitance }\end{array}$ & $\begin{array}{l}25-94 \& x \\
115-275^{\circ} \mathrm{C}\end{array}$ & $2.0-2.3 \mathrm{~J} / \mathrm{cm}^{3}-. . \mathrm{K}$ & DOE, 1994 & \\
\hline $\mathrm{p}$ & $95-114^{\circ} \mathrm{C}$ & $11 \mathrm{~J} / \mathrm{cm}^{3}{ }^{\circ} \mathrm{K}$ & " & (dehydration) \\
\hline $\begin{array}{l}\text { thermal } \\
\text { expan. coeff. }\end{array}$ & $25-100^{\circ} \mathrm{C}$ & $7.7-10.8 \times 10^{-6}{ }^{\circ} \mathrm{K}^{-1}$ & Martin et al., 1996 & $\begin{array}{l}\text { lab. tests on } \\
\text { cores }\end{array}$ \\
\hline & 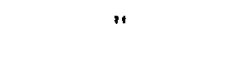 & $5.4-9.1 \times 10^{-6}{ }^{\circ} \mathrm{K}^{-1}$ & DOE, 1994 & 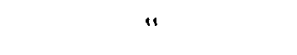 \\
\hline " & near $250^{\circ} \mathrm{C}$ & $14.2-20.6 \times 10^{-6}{ }^{\circ} \mathrm{K}^{-1}$ & Martin et al., 1996 & $"$ \\
\hline & 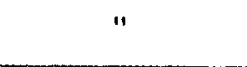 & $25-35.6 \times 10^{-6}{ }^{\circ} \mathrm{K}^{-1}$ & DOE, 1994 & $"$ \\
\hline
\end{tabular}




\section{REFERENCES}

Ahola, M. P. et al. (1995), NRC High-Level Radioactive Waste Research at CNWRA July-December 1994, Center for Nuclear Waste Regulatory Analyses, San Antonio, Texas, CNWRA 94-02S.

Ahola, M. P. et al. (1996), NRC High-Level Radioactive Waste Research at CNWRA July - December 1995, Center for Nuclear Waste Regulatory Analyses, San Antonio, Texas, CNWRA 95-02S.

Arulmoli, K., and C. M. St. John (1987), Analysis of Horizontal Waste Emplacement Boreholes of a Nuclear Waste Repository in Tuff, Sandia National Laboratories, Albuquerque, NM, SAND86-7133.

Auld, B. A. (1973), Acoustic Fields and Waves in Solids, Vol. 1 and 2, John Wiley \& Sons, New York.

Baecher, G. B., N. A. Lanney, and H. H. Einstein (1977), Statistical Descriptions of Rock Propcrtics and Sampling, Proc. 18th U. S. Symp. Rock Mech, Colorado School of Mines Press, Golden, CO.

Barr, G. E., D. J. Borns, and C. Fridrich (1996), Scenarios Constructed for the Effects of the Tectonic Processes on the Potential Nuclear Waste Repository at Yucca Mountain, Sandia National Laboratories, Albuquerque, NM, SAND96-1132.

Barton, C. A., S. Hickman, M. D. Zoback, R. Morin, T. Finkbeiner, J. Sass, and D. Benoit (1996), Fracture permeability and its relationship to in situ stress in the Dixie Valley, Nevada, Geothermal Reservoir, in: Proceed. 8th Int. Symp. on Observations of the Continental Crust through Drilling, Tsukuba, Japan, Feb., 210-215.

Barton, C. A., M. D. Zoback, and D. Moos (1995), Fluid Flow Along Potentially Active Faults in Crystalline rock, Geology Vol. 23, No. 8, 683-686.

Berryman, J. G. (1996), Mixture Theories for Rock Properties, in: Rock Physics \& Phase Relations, A Handbook of Physical Constants, AGU Reference Shelf 3, T. J. Ahrens, ed., American Geophysical Union, Washington, DC, 205-228.

Blair, S. (1994), Analysis of Compressive Fracture in Rock Using Statistical Techniques, Ph.D. Thesis, U.C. Berkeley, and Lawrence Livermore National Laboratory, Livermore, CA, UCRL-LR-120950.

Blair, S. C., and P. A. Berge (1996), Chapter 4.0, Geomechanics, in: Near-Field and Altered-Zone Environment Report, Vol. II, D. G. Wilder, ed., Lawrence Livermore National Laboratory, Livermore, CA, UCRL-LR-124998, pp. 4-1 to 4-34. 
Blair, S. C., P. A. Berge, and H. F. Wang (1996), Geonechanical Analysis of the Large Block Test, Lawrence Livermore National Laboratory, Livermore, CA, UCRL-ID122898.

Blair, S. C., J. M. Kelly, O. Pine, R. Pletcher, and P. A. Berge (1996), Effect of Radiation on the Mechanical Properties of Topopah Spring Tuff, Lawrence Livermore National Laboratory, Livermore, CA, UCRL-ID-122899.

Blair, S. C., and P. A. Berge (1997), Geomechanical Properties of Topopah Spring Tuff at the $0.5 \mathrm{~m}$ Scale: Preliminary Results of Compression Tests at Elevated Temperature, lawrence Livermore National laboratory, Livermore, CA, UCRLID-125089.

Borgesson, L., and J. Hernelind (1995a), DECOVALEX I - Test Case 2: Calculation of the Fanay-Augeres GHM Test - Thermomechanical Modelling of a Fractured Rock Volume, Swedish Nuclear Fuel and Waste Management Company, Stockholm, Sweden, SKB Technical Report 95-28.

Borgesson, L., and J. Hernelind (1995b), DECOVALEX I - Test Case 3: Calculation of the BIG BEN Experiment - Coupled Modelling of the Thermal, Mechanical and Hydraulic Behaviour of Water-Unsaturated Buffer Material in a Simulated Deposition Hole, Swedish Nuclear Fuel and Waste Management Company, Stockholm, Sweden, SKB Technical Report 95-29.

Case, J. B., and P. C. Kelsall (1987), Modification of Rock Mass Permeability in the Zone Surrounding a Shaft in Fractured, Welded Tuff, Sandia National Laboratories, Albuquerque, NM, SAND86-7001.

Cundall, P. A. (1976), Explicit finite difference methods in geomechanics, in: Numerical Methods in Engineering, in: Proceedings of the EF Conference on Numerical Methods in Geomechanics, Blacksburg, Virginia, Vol. I, 132-150.

Cundall, P. A. (1980), UDEC - A Generalized Distinct Element Program for Modelling Jointed Rock, Peter Cundall Assoc., Report PCAR-1-80; U.S. Army, European Research Office, Contract DAJA37-79-C-0548, March.

Cundall, P. A., and R. D. Hart (1993), Numerical Modeling of Discontinua, in: Comprehensive Rock Engineering; Principles, Practice \& Projects, J. A. Hudson, ed., Pergamon Press, Oxford, United Kingdom, 231-243.

Darot, M., Y. Gueguen, and M.L. Baratin (1992), Permeability of Thermally Cracked Granite, Geophysical Research Letters, Vol. 19, No. 9, 869-872. 
DOE (U. S. Department of Energy) (1994), Yucca Mountain Project Reference Information Base, Version 4, Yucca Mountain Site Characterization Project Office, Las Vegas, NV, YMP/CC-0002.

Einstein, H. H., and W. S. Dershowitz (1990), Tensile and Shear Fracturing in Predominantly Compressive Stress Fields-n A Review, Eng. Geology Vol. 29, 149172.

Gale, J. E., and K. G. Raven (1980), Effect of Sample on Stress-Permeability Relationships for Natural Fractures, Lawrence Berkeley Laboratory, Berkeley, California, Technical Information Report No. 48, LBL-11865, SAC-48,UC-70.

Ge, S. (1997), A Governing Equation for Fluid Flow in Rough Fractures, Water Sources Research, Vol. 33, No. 1, 53-61.

Golder Associates, Inc. (1990), MAFIC (Matrix/Fracture Interaction Code with Solute Transport) User Documentation, prepared by I. Miller, Redmond, WA, 48 pp. +4 appendices.

Golder Associates, Inc. (1993), FracMan User Documentation, prepared by W. Dershowitz, G. Lee, J. Geier, S. HItchcock, P. LaPointe, Seattle, WA, 154pp. +5 appendices.

Hart, R. D., and P. A. Cundall (1992), Microcomputer Programs for Explicit Numerical Analysis in Geotechnical Engineering, paper presented at Int. Seminar on Numerical Methods in Geomechanics, Moscow.

R. D. Hart (1993), An Introduction to Distinct Element Modeling for Rock Engineering, in: Comprchensive Rock Engineering; Principles, Practice \& Projects, J. A. Hudson, ed., Pergamon Press, Oxford, United Kingdom, 245-261.

Hibbitt, Karlsson \& Sorensen, Inc. (1994), ABAQUS/Standard User's Manual (Version 5.4), Vols. I and II, Pawtucket, RI.

Hoek, E., and E. T. Brown (1980), Underground Excavation in Rock, The Institute of Mining and Metallurgy, London, United Kingdom.

Hsuing, S. M., A. Ghosh, A. H. Chowdhury, and M. P. Ahola (1994), Evaluation of Rock Joint Models and Computer Code UDEC Against Experimental Results, Center for Nuclear Waste Regulatory Analyses, Southwest Research Institute, and Nuclear Regulatory Commission, Washington, D.C. , NUREG/CR-6216, CNWRA 93-024.

Israelsson, J. (1995), DECOVALEX I - Bench-Mark Test 3: Thermo-Hydro-Mechanical Modelling, Swedish Nuclear Fuel and Waste Management Company, Stockholm, Sweden, SKB Technical Report 95-30. 
Itasca Consulting Group, Inc. (1993), FLAC User's Manual, Vol. I-III, Minneapolis, MN.

Itasca Consulting Group, Inc. (1996), FLAC 3D Fast Lagrangian Analysis of Continua in 3 Dimensions, Version 1.1, User's Manuals, Vol. I-lll, Minneapolis, MN.

Jaeger, J. C., and N. G. W. Cook (1976), Fundamentals of Rock Mechanics, Halsted Press, London.

Jing, L., C. F. Tsang, and O. Stephansson (1995), DECOVALEX - An International CoOperative Research Project on Mathematical Models of Coupled THM Processes for Safety Analysis of Radioactive Waste Repositories, Int. I. Rock Mech. Min. Sci. \& Geomech. Abstr. Vol. 32, No. 5, 389-398.

LeCain, G. D., and J. N. Walker (1994), Results of Air-Permeability Testing in a Vertical Borehole at Yucca Mountain, Nevada, in: Proceedings of the Fifth Annual International Conference on High Level Radioactive Waste Management, Las Vegas, NV, May 22-26, 1994, American Nuclear Society, La Grange Park, IL, 2782-2788.

Lin, M., M. P. Hardy, and S. J. Bauer (1993), Fracture Analysis and Rock Quality Designation Estimation for the Yucca Mountain Site Characterization Project, Sandia National Laboratories, Albuquerque, NM, SAND92-0449.

Lin, W., and A. Ramirez (1996), Chapter 9.0, Field Thermal Tests, in: Near-Field and Altered-Zone Environment Report, Vol. II, D. G. Wilder, ed., Lawrence Livermore National Laboratory, Livermore, CA, UCRL-LR-124998, pp. 9-1 to 9-42.

Lin, W., and J. Roberts (1996), Chapter 2.0, Laboratory-Determined Hydrologic Properties and Processes, in: Near-Field and Altered-Zone Environment Report, Vol. II, D. G. Wilder, ed., Lawrence Livermore National Laboratory, Livermore, CA, UCRL-LR-124998, pp. 2-1 to 2-31.

Lin, W., D. Wilder, J. Blink, P. Berge, S. Blair, V. Brugman, R. Carlson, K. Lee, M. Owens, R. Pletcher, N. Rector, J. Roberts, D. Ruddle, S. Sommer, T. Ueng, and J. Wagoner (1995), The Large Block Test, A Progress Report, in: Proceedings of the Sixth Annual International Conference on High Level Radioactive Waste Management, Las Vegas, NV, April 30-May 5, 1995, American Nuclear Society, La Grange Park, IL, 46-47.

Lin, W., D. Wilder, J. Blink, P. Berge, S. Blair, V. Brugman, K. Lee, M. Owens, C. Radewan, A. Ramirez, N. Rector, J. Roberts, D. Ruddle, and J. Wagoner (1996), A Progress Report on the Large Block Test, in: Proceedings of the Seventh Annual International Conference on High Level Radioactive Waste Management, Las 
Vegas, NV, April 29-May 3, 1996, American Nuclear Society, La Grange Park, H, 122-123.

MacDougall, H.R., L.W. Scully, and J. R. Tillerson (Compilers) (1987), Site Characterization Plan Conceptual Design Report, Sandia National Laboratories, Albuquerque, NM, SAND84-2641.

Martin, R. J. III, R. H. Price, P. J. Boyd, and W. Haupt (1992), Anisotropy of the Topopah Spring Member Tuff, Sandia National Laboratories, Albuquerque, NM, SAND91-0894.

Martin, R. J., III, R. H. Price, P. J. Boyd, and J. S. Noel (1993), Unconfined Compression Experiments on Topopah Spring Member Tuff at 22 deg. $C$ and a Strain Rate of $10^{-9} \mathrm{~s}^{-1}$ : Data Report, Sandia National Laboratories, Albuquerque, NM, SAND91-0894.

Martin, R. J., R. H. Price, P. J. Boyd, and J. S. Noel (1994), Bulk and Mechanical Properties of the Paintbrush Tuff Recovered from Borehole USW NRG-6: Data Report, Sandia National Laboratories, Albuquerque, NM, SAND93-4020.

Martin, R. J., R. H. Price, P. J. Boyd, and J. S. Noel (1995), Bulk and Mechanical Properties of the Paintbrush Tuff Recovered from Borchole USW NRG-7/7A: Data Report, Sandia National Laboratories, Albuquerque, NM, SAND94-1996.

Martin, R. J., R. H. Price, J. S. Noel, and P. J. Boyd (1996), Thermal Expansion Coefficient as a Function of Confining Pressure for Welded Tuff from Yucca Mountain, in: Rock Mechanics Tools and Techniques, M. Aubertin, F. Hassani, and H. Mitri, eds., Proceedings of the 2nd North American Rock Mechanics Symposium, Montreal, Canada, June 19-21, 1996, A. A. Balkema Publishers, Rotterdam, Netherlands, 1659-1666.

Mohanty, S., A. H. Chowdhury, S. M. Hsiung, and M. P. Ahola (1994), Single Fracture Flow Behavior of Apache Leap Tuff Under Normal and Shear Loads, Center for Nuclear Waste Regulatory Analyses, San Antonio, Texas, CNWRA 94-024.

Nimick, F. B. (1990), The Thermal Conductivity of Seven Thermal Mechanical Units at Yucca Mountain. Nevada, Sandia National Laboratories, Albuquerque, NM, SAND88-1387.

Olsson, W. A., and S. R. Brown (1994), Mechanical Properties of Seven Fractures from Drillholes NRG-4 and NRG-6 at Yucca Mountain, Nevada, Sandia National Laboratories, Albuquerque, NM, SAND94-1995.

Preuss, K., and T. N. Narasimhan (1985), A Practical Method for Modeling Fluid and Heat Flow in Fractured Porous Media, Soc. of Petr. Eng. I., Vol. 25, No. 1, 14-26. 
Price, R. H., (1986), Effects of Sample Size on the Mechanical Behavior of Topopah Spring Tuff, Sandia National Laboratories, Albuquerque, NM, SAND85-0709.

Price, R. H., J. R. Connolly, and K. Keil (1987), Petrologic and Mechanical Properties of Outcrop Sumples of the Welded, Devitrified Topopah Spring Member of the Paintbrush Tuff, Sandia National Laboratories, Albuquerque, NM, SAND86-1131.

Price, R. H., R. J. Martin, III, and R. W. Haupt (1994), The Effect of Frequency on Young's Modulus and Seismic Wave Attenuation, Sandia National Laboratories, Albuquerque, NM, SAND92-0847.

Raven, K. G., and J. E. Gale (1985), Water Flow in a Natural Rock Fracture as a Function of Stress and Sample Size, Int. J. Rock Mech. Sci. and Geomech. Abstr. Vol. 22, No. 4, 251-261.

Rosengren, L., and M. Christianson (1995), DECOVALEX I - Test Case 1: Coupled Stress-Flow Model, Swedish Nuclear Fuel and Waste Management Company, Stockholm, Sweden, SKB Technical Report 95 31.

Rothman, D. H. (1988), Cellular-Automaton Fluids: A Model for Flow in Porous Media, Geophysics, Vol. 53, No. 4, 509-518.

Stock, J. M., J. H. Healy, and S. H. Hickman (1984), Report on Televiewer Log and Stress Measurements in Core Hole USW G-2, Nevada Test Site, U. S. Geological Survey, Denver, CO, OFR-84-172.

Stock, J. M., J. H. Healy, S. H. Hickman, and M. D. Zoback (1985), Hydraulic Fracturing Stress Measurements at Yucca Mountain, Nevada, and Relationship to Regional Stress Field, I. Geophys. Res. Vol. 90, No. B10, 8691-8706.

TRW Environmental Safety Systems Inc. (1996), Characterization of the ESF Thermal Test Area, Las Vegas, NV, B-01717-5705-00047 REV 01.

Zhang, X., and D. J. Sanderson (1996), Effects of Stress on the Two-Dimensional Permeability Tensor of Natural Fracture Networks, Geophysical Journal International, Vol. 125, No. 3.

Zimmerman, R. M., R. L. Schuch, D. S. Mason, M. L. Wilson, M. E. Hall, M. P. Board, R. P. Bellman, and M. L. Blanford (1986), Final Report: G-Tunnel Heated Block Experiment, Sandia National Laboratories, Albuquerque, NM, SAND842620. 